\title{
Three Sudanese sorghum-based fermented foods (kisra, hulu-mur and abreh): Comparison of proximate, nutritional value, microbiological load and acrylamide content
}

\author{
Abdalbasit A. Mariod ${ }^{1,2}$, Yousif M.A. Idris' \\ Nuha M. Osman', Maha A. Mohamed ${ }^{3}$, \\ Awad M.A. Sukrab ${ }^{3}$, Marwa Y. Farag ${ }^{4}$, B. Matthaus ${ }^{5}$ \\ 1 - College of Science \& Arts, University of Jeddah, Alkamil, KSA. \\ 2 - Sudan University of Sci. \& Technology, Shambat, Khartoum North, Sudan. \\ 3 - Sudanese Standards and Metrology Organization, Khartoum, Sudan, \\ 4 - Food Research Center, Shambat, Khartoum North, Sudan. \\ 5 - Max Rubner-Institute, Working Group for Lipid Research, Detmold, Germany.
}

Keywords:

Fermentation

Sorghum

Abreh

Hulu-mur

Kisra

Composition

Article history:

Received 14.10.2016

Received in revised form 21.12.2016

Accepted 30.12.2016

Corresponding author:

Abdalbasit A. Mariod

E-mail:

basitmariod58@gmail.com

DOI: $10.24263 / 2310$

1008-2016-4-2-4

\section{Abstract}

Introduction. This article aims to compare the proximate, nutritional value, microbiological load and acrylamide content of Tabat and Feterita flour and theirbased fermented foods (Kisra, hulu-mur and abreh).

Materials and methods. Two sorghum varieties (Tabat, and Feterita) were stone milled into fine flour. Kisra, Hulu-mur and Abreh batters were prepared according to the traditional way employed in Sudanese household. The fermented batters, were baked. Sajj or doka an iron plate $60 \times 40 \mathrm{~cm}$ was used for baking. The AOAC method was followed to investigate proximate analysis, carbohydrate, mineral and amino acid content. While acrylamide was determined by a GC-MS.

Results and discussion. A significant $(P<0.05)$ difference in the composition of the flours and the fermented foods was observed. During Kisra preparation, a significant decrease in fiber, oil and carbohydrate contents was observed. Germination followed by fermentation during processing of kisra and hulu-mur batter lead to a significant $(P \leq 0.05)$ decline in fiber, oil and carbohydrate contents. Glutamic, aspartic, leucine and proline represented the highest values among the whole amino acids of Tabat and Feterita and their-based foods (kisra, hulu-mur), whereas cysteine and methionine were the least ones. There was a significant difference $(P<0.05)$ in total lactic acid bacteria count of different batters. Acrylamide was detected in two samples only.

Conclusion. Kisra, abreh and hulu-mur products were found to have appreciable nutritional quality. 


\section{Introduction}

Sorghum bicolor (family Poaceae), represents the most important staple food for $40 \%$ of Sudan's population with a remarkable degree of rural consumption. The mechanized rain-fed sorghum is the more contributing production wise. It accounts for more than $60 \%$ of sorghum total production in Sudan [1]. Sorghum is insufficient in lysine, threonine, and tryptophan, and rich in leucine, proline and glutamic acid. Both fermentation and germination affected sorghum proteins, but with different mechanisms. Germination resulted in the significant breakdown of sorghum starch. Fermented sorghum flour gave rice pasta with improved cooking properties [2]. In many parts of Sudan, people consume whole grain sorghum as fermented flat bread (Kisra), thick porridge (Aceda), thin fermented gruel (Nasha), boiled grain (Balela) and beverages like Abreh and Hulu-mur [3].

Acrylamide or 2-propenamide is a chemical compound, that can be created at abnormal states in high-carbohydrate heat-treated foods. Elements influencing acrylamide composition and degradation in foods are acrylamide precursors for example free amino acids (mainly asparagine), reducing sugars and preparing conditions (i.e. baking time and temperature, moisture content and framework of the item) [4]. This study aims to compare between three Sudanese sorghum-based fermented foods (kisra, hulu-mur and abreh) for their proximate composition, nutritional value, microbiological load and acrylamide content

\section{Materials and methods}

Sample collection. Two sorghum varieties, named in Sudan as Tabat, and Feterita were collected from the grain market in Khartoum North, Sudan, and were stone milled into fine flour. The flour was stored at $25^{\circ} \mathrm{C}$ until used.

Preparation and baking of sorghum kisra batter. Sorghum kisra batter fermentation and baking were carried out in a conventional way following Mahgoub et al. [3]. A natural fermentation was done by microorganisms found in the previously fermented batter. The fermented batter, (known as Ajin is thin to behave like a liquid). Samples were calculated in triplicate.

Hulu-mur dough preparation and baking procedures. Hulu-mur dough was prepared following the conventional way utilized in Sudanese household [5]. The dough was kept in a refrigerator at $4^{\circ} \mathrm{C}$ for chemical analysis. Sajj or doka an iron plate $60 \times 40$ $\mathrm{cm}$ was used for baking of hulu-mur.

Abreh batter preparation and baking. Abreh batter was prepared according to the traditional way employed in Sudanese household. The process of baking the fermented batter is done following Mahgoub et al. [3].

Proximate analysis. Moisture, ash, lipid, and crude fiber contents were investigated following the AOAC method [6]. The carbohydrate percentage was calculated by difference. All analyses were carried out in triplicate.

Carbohydrates and mineral content procedure. Soluble carbohydrates from 4 grams of every flour and processed samples were separated with $50 \mathrm{~mL}$ of $80 \%$ ethanol at $60^{\circ} \mathrm{C}$ for $30 \mathrm{~min}$. Separation and quantization were carried out on bonded column with a 
versatile stage of $\mathrm{CH}_{3} \mathrm{CN}$ and water $(80: 20 \mathrm{~V}: \mathrm{V})$. The AOAC method [6] was utilized to determine minerals. All analyses were carried out in triplicate.

Determination of amino acids. Amino acids were analyzed following AOAC [6] procedures and separated using Amino Acids Analyzer (Beckman Coulter, Mannheim, Germany). The chemical score was calculated, following Stipanuk \& Caudill [7]. All analyses were performed in triplicate.

Acrylamide determination. Acrylamide was determined by a GC-MS method in the EI mode after extraction of acrylamide from the food material. The quantification was carried out by ions with masses 71 and 74 . The separation was completed with a DB-23 capillary column (J\&W Scientific Products GmbH, Köln, Germany) (30 m x 0.25 mm i.d., $0.25 \mathrm{~mm}$ film thickness). The carrier gas was helium at a stream rate of $1.0 \mathrm{~mL} / \mathrm{min}$. The column temperature was at first kept at $80{ }^{\circ} \mathrm{C}$ for $2 \mathrm{~min}$ and afterward expanded from 80 ${ }^{\circ} \mathrm{C}-220{ }^{\circ} \mathrm{C}$ at $10^{\circ} / \mathrm{min}$. The acrylamide limit of determination was $<10 \mu \mathrm{g} / \mathrm{kg}$ in all food materials tested [8-9].

Microbial analysis and total viable count of bacteria. The Plate Count Agar (PCA) was incubated at $37^{\circ} \mathrm{C}$ for $48 \mathrm{~h}$. The inoculation was spread all over the plate using sterile bent glass rod (L) shape. The plate was incubated at $37^{\circ} \mathrm{C}$ for $2-3$ days $(48-72 \mathrm{~h}$ ) [10]. In all cases, the bacterial, yeast and mold counts were converted into log CFU g before analysis. All tests were carried out three times.

Statistical analysis. Representative random samples were drawn for analysis. Onefactor Complete Randomize Design (CRD) was performed. Data were analyzed using the Analysis of Variance (ANOVA). Duncan's multiple range test (DMR) was used to separate means. Significance was accepted at $\mathrm{P} \leq 0.05$ using a statistical program (SPSS version 20). Three replicates were carried out for each determination [11].

\section{Results and discussion}

\section{Proximate composition}

Table (1) shows the proximate composition of dry matter, ash, fiber, protein, oil and carbohydrate of Tabat, and Feterita sorghum cultivars flour and their-based foods on a dry basis. The dry matter of Tabat, and Feterita sorghum cultivars flour was assessed as 96.17 $\%$, and $97.19 \%$, respectively. No significant $(p \geq 0.05)$ change was found in the dry matter between Tabat and Feterita flours. Ash content of Tabat flour was found to be $0.89 \%$, which was significantly $(p \leq 0$. 05) lower than that of Feterita flour $(1.0 \%)$. Toum [12] reported very high $(2.38 \%)$ ash content of Tabat flour. Dietary fiber is all parts of a plant we eat that contain carbohydrates that are resistant to digestion and absorption in the human digestive system. The fiber content of Tabat sorghum cultivar flour was detected at $0.96 \%$, which was significantly $(p \leq 0.05)$ lower than that of Feterita flour $(8.03 \%)$. Awadelkareem, et al. [13] recorded lower fiber content of Feterita at 2.1 and $2.02 \%$, respectively. Toum [12] reported very high fiber content $(2.86 \%)$ for Tabat flour may be due to climatic or location differences.

The protein content of Tabat flour was found to be $12.24 \%$, which was significantly $(p \leq 0.05)$ lower than that of Feterita flour $(13.10 \%)$. The results obtained were similar to that reported by Awadelkareem, et al. ${ }^{13}$ who recorded 13.4\%. While Toum [12] reported 
9.75\% for Tabat crude protein. The oil content of Tabat flour (3.1\%) was approximately similar to that of Feterita flour (3.12\%). Toum [12] reported 2.8\% as oil content for Tabat cultivar. The carbohydrate content of Tabat flour was found to be (78.99\%) (Table 1) which was significantly $(p<0.05)$ higher than that of Feterita flour $(72.36 \%)$. Toum [12] reported lower carbohydrate content $(74.9 \%)$ for Tabat cultivar. While Awadelkareem et al. [13] reported $72.4 \%$ as the carbohydrate content for Feterita.

Table 1

Proximate composition of Tabat, and Feterita sorghum cultivars flour and their-based foods on dry basis*

\begin{tabular}{|c|c|c|c|c|c|c|}
\hline 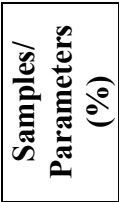 &  & $\frac{\pi}{4}$ & 这 & 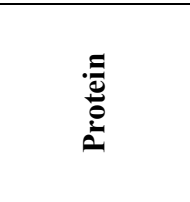 & $\bar{\sigma}$ & 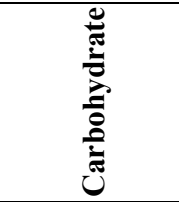 \\
\hline $\mathrm{T}$ & $96.17 \pm(0.45)^{\mathrm{a}}$ & $0.89 \pm(0.01)^{\mathrm{a}}$ & $0.96 \pm(0.03)^{\mathrm{a}}$ & $12.24 \pm(0.06)^{\mathrm{a}}$ & $3.10 \pm(0.61)^{\mathrm{a}}$ & $78.99 \pm(0.62)^{\mathrm{a}}$ \\
\hline TB & $15.74 \pm(0.43)^{\mathrm{b}}$ & $2.32 \pm(0.13)^{\mathrm{b}}$ & $1.93 \pm(0.17)^{\mathrm{b}}$ & $11.59 \pm(0.09)^{\mathrm{b}}$ & $5.82 \pm(1.73)^{\mathrm{b}}$ & $67.29 \pm(1.71)^{\mathrm{b}}$ \\
\hline TK & $49.94 \pm(0.16)^{\mathrm{c}}$ & $2.82 \pm(0.04)^{\mathrm{c}}$ & $2.45 \pm(0.29)^{\mathrm{c}}$ & $14.47 \pm(0.21)^{\mathrm{c}}$ & $2.06 \pm(0.60)^{\mathrm{c}}$ & $72.37 \pm(0.48)^{\mathrm{c}}$ \\
\hline \begin{tabular}{|l|} 
THBS \\
\end{tabular} & $23.70 \pm(0.34)^{\mathrm{d}}$ & $2.39 \pm(0.09)^{\mathrm{d}}$ & $3.01 \pm(0.16)^{\mathrm{d}}$ & $10.78 \pm(0.07)^{\mathrm{d}}$ & $3.23 \pm(1.16)^{\mathrm{d}}$ & $69.37 \pm(1.15)^{\mathrm{d}}$ \\
\hline THAS & $25.69 \pm(0.40)^{\mathrm{e}}$ & $1.82 \pm(0.07)^{\mathrm{e}}$ & $1.75 \pm(0.14)^{\mathrm{e}}$ & $10.51 \pm(0.16)^{\mathrm{e}}$ & $3.96 \pm(0.45)^{\mathrm{e}}$ & $70.90 \pm(0.53)^{\mathrm{e}}$ \\
\hline TH & $93.85 \pm(0.05)^{\mathrm{f}}$ & $2.30 \pm(0.04)^{\mathrm{f}}$ & $2.93 \pm(0.11)^{\mathrm{d}}$ & $10.41 \pm(0.06)^{\mathrm{f}}$ & $2.36 \pm(0.32)^{\mathrm{f}}$ & $75.85 \pm(0.37)^{f}$ \\
\hline TABS & $92.56 \pm(0.02)^{\mathrm{b}}$ & $1.77 \pm(0.08)^{b}$ & $2.04 \pm(0.13)^{b}$ & $11.66 \pm(0.14)^{\mathrm{b}}$ & $3.12 \pm(0.25)^{\mathrm{b}}$ & $73.96 \pm(0.52)^{b}$ \\
\hline TAAS & $92.54 \pm(0.57)^{\mathrm{b}}$ & $2.43 \pm(0.06)^{\mathrm{cd}}$ & $1.82 \pm(0.19)^{\mathrm{c}}$ & $12.26 \pm(0.07)^{\mathrm{a}}$ & $3.27 \pm(0.58)^{\mathrm{c}}$ & $72.77 \pm(0.70)^{\mathrm{c}}$ \\
\hline TA & $88.87 \pm(0.15)^{\mathrm{d}}$ & $2.52 \pm(0.06)^{\mathrm{d}}$ & $1.74 \pm(0.23)^{\mathrm{c}}$ & $12.17 \pm(0.12)^{\mathrm{c}}$ & $3.52 \pm(0.29)^{\mathrm{d}}$ & $68.92 \pm(0.27)^{d}$ \\
\hline $\mathrm{F}$ & $97.19 \pm(0.66)^{\mathrm{a}}$ & $1.00 \pm(0.03)^{\mathrm{b}}$ & $8.03 \pm(0.99)^{b}$ & $13.10 \pm(0.06)^{b}$ & $3.12 \pm(0.39)^{\mathrm{ab}}$ & $72.36 \pm(0.78)^{b}$ \\
\hline FB & $18.76 \pm(0.29)^{\mathrm{b}}$ & $1.89 \pm(0.02)^{\mathrm{c}}$ & $2.03 \pm(0.10)^{\mathrm{c}}$ & $14.24 \pm(0.12)^{\mathrm{c}}$ & $3.11 \pm(0.23)^{\mathrm{ac}}$ & $69.44 \pm(0.15)^{\mathrm{c}}$ \\
\hline FK & $49.81 \pm(0.06)^{c}$ & $2.65 \pm(0.06)^{\mathrm{d}}$ & $2.00 \pm(0.24)^{\mathrm{c}}$ & $14.25 \pm(0.12)^{\mathrm{d}}$ & $1.88 \pm(0.36)^{\mathrm{f}}$ & $71.22 \pm(0.52)^{\mathrm{d}}$ \\
\hline FHBS & $21.91 \pm(0.12)^{\mathrm{d}}$ & $2.13 \pm(0.08)^{\mathrm{e}}$ & $1.83 \pm(0.06)^{\mathrm{d}}$ & $14.12 \pm(0.16)^{\mathrm{de}}$ & $1.83 \pm(0.23)^{\mathrm{df}}$ & $66.18 \pm(0.23)^{\mathrm{e}}$ \\
\hline FHAS & $21.71 \pm(0.36)^{\mathrm{e}}$ & $2.06 \pm(0.01)^{\mathrm{e}}$ & $2.20 \pm(0.26)^{\mathrm{e}}$ & $14.02 \pm(0.10)^{\mathrm{e}}$ & $2.78 \pm(0.85)^{\mathrm{e}}$ & $66.89 \pm(0.74)^{\mathrm{e}}$ \\
\hline \begin{tabular}{|l|}
$\mathrm{FH}$ \\
\end{tabular} & $95.48 \pm(0.08)^{\mathrm{f}}$ & $2.20 \pm(0.11)^{\mathrm{f}}$ & $2.47 \pm(0.28)^{\mathrm{f}}$ & $13.30 \pm(0.01)^{\mathrm{f}}$ & $1.73 \pm(0.19)^{\mathrm{f}}$ & $75.85 \pm(0.48)^{\mathrm{f}}$ \\
\hline
\end{tabular}

*T: Tabat flourghjk sample. TB: Tabat batter sample. TK: Tabat Kisra sample. THBS: Tabat hulumur batte before adding spices sample. THAS: Tabat hulu-mur batter after adding spices sample. TH: Tabat hulu-mur sample. F: Feterita flour sample. FD: Feterita batter sample. FK: Feterita Kisra sample. FHBS: Feterita hulu-mur batter before adding spices sample. FHAS: Feterita hulu-mur batter after adding spices sample. FH: Feterita hulu-mur sample. TABS: Tabat Abreh batter before adding spices sample. TAAS: Tabat Abreh batter before adding spices sample .TA: Tabat Abreh sample. Values are means $( \pm \mathrm{SD}$ ). Values not sharing a common superscript in a column (for $\mathrm{T}, \mathrm{F}$ and $\mathrm{S}$ separately) are significantly $(\mathrm{P} \leq 0.05)$ different.

These differences in ash, fiber, protein and carbohydrate contents in Table 1 might be due to genetic variations between seeds of the two cultivars. For both cultivars when the flour was fermented during kisra preparation, significant decrease in ash, fiber, protein, oil and carbohydrate contents were observed. Baking of fermented kisra batter of both cultivars $($ Aowasa) significantly $(p<0.05)$ increase ash, fiber, protein, oil and carbohydrate contents. The concentration of vitamins, minerals, and protein appear to increase as a result of fermentation when measured on dry weight basis [14]. Table 1, shows the protein content of Tabat flour 12.24\%, Tabat kisra batter 11.59\%, Tabat kisra 14.47\%. These results showed a significant $(P \leq 0.05)$ difference in the content as a result of fermentation and baking process, as the protein content of Tabat flour, increased in Tabat kisra. This increase can be related to the loss of dry matter mainly carbohydrates [15]. 
From Table 1, the protein content of Tabat flour is $12.24 \%$ and it was decreased in Tabat hulu-mur batter before adding spices to $10.78 \%$, and to $10.51 \%$ in Tabat hulu-mur batter after adding spices, and to $10.41 \%$ in Tabat hulu-mur. There was a significant $(P \geq$ 0.05 ) decrease in protein content from 12.24 to $10.41 \%$ during Tabat hulu-mur batter fermentation. This reduction may be identified with germination and malting forms as malting is a biotechnological strategy which includes the controlled germination of a cereal grain, which goes for initiating enzyme systems that catalyze the hydrolysis of polymerized reserved food materials, notably, proteins, starches and cell-wall substances, thus, extracting fermentable materials [16]. The slight change in protein content may attribute to the fact that water-soluble nitrogen was lost during soaking of seeds (sorghum seeds were soaked prior germination) and also, during seed germination, part of the protein was utilized for the development and advancement of the embryo [17].

The carbohydrate content of Tabat flour was $78.99 \%$, and that of Tabat kisra batter was $67.29 \%$, and Tabat kisra was $72.37 \%$ (Table1). While the carbohydrate content of Tabat hulu-mur batter before adding spices was $69.37 \%$, and Tabat hulu-mur batter after adding spices was $70.90 \%$, and Tabat hulu-mur was $75.85 \%$. Table 1 clearly indicates a significant $(P \geq 0.05)$ decrease in carbohydrate content with fermentation. This is due to microbial activity on Tabat fermentation. The available carbohydrates are converted to organic acids due to the fermentation process and significantly $(P \geq 0.05)$ reduced the amount of carbohydrates which may be attributed to the utilization of sugars by the fermenting microflora [18].

The proximate composition of Abreh produced from Tabat cultivar is given in Table 1. The ash, fiber, protein, oil and carbohydrate contents of Tabat flour and Abreh product were significantly $(P \leq 0.05)$ different. In the decorticated sorghum, the germ was partly or completely removed. This may have nutritious results as the germ contains most minerals and lipids. During Abreh processing the seeds first decorticated so this decortication had numerous effects on grain composition. The protein content of Tabat flour was $12.24 \%$ it was signed $(\mathrm{P} \leq 0.05)$ decreased to $11.66 \%$ in Abreh batter before the addition of spices, this decrease was related to a fermentation process. No significant $(\mathrm{P} \leq 0.05)$ difference in protein content of Tabat flour and Abreh as a final product.

The proximate composition of Feteria flour and its based products (Kisra and Hulumur) is given in Table 1. The ash, fiber, protein, oil and carbohydrate contents of Feterita flour and its based products (Kisra and Hulu-mur) were significantly $(P \leq 0.05)$ different. When the flour was fermented during Kisra preparation, a significant decrease in fiber, oil, and carbohydrate contents were observed. While the crude protein content was increased by fermentation. These results are in good agreement with that of EI Tinay et al. [19] who reported a slight increase in protein content of Kisra produced from three sorghum varieties as a result of fermentation. Adams [14] reported an increase in the concentration of minerals and protein as result of cereal fermentation.

Baking of fermented kisra batter (Aowasa) significantly $(p<0.05)$ increase ash, and protein contents. These results were disagreeing with the results of Elkhalifa et al. [20] who reported that, the protein content of Kisra was slightly lower than the value for its fermented batter.

The proximate composition of Feteria flour and it is based product Hulu-mur is given in Table 1. The ash, fiber, protein, oil and carbohydrate contents of Feterita flour and that of Hulu-mur produced from it were significantly $(P \leq 0.05)$ different. Germination of Feterita seeds followed by fermentation during processing of hulu-mur batter lead to a significant $(P \leq 0.05)$ decline in fiber, oil and carbohydrate contents, and a slight increase of ash and protein, respectively. These outcomes are in good agreement with that of Mella 
[21] who reported that fermentation brought about an expansion in the amounts of soluble proteins and the free amino acids. Malting and fermentation pre-treatments can enhance the composition and functionality of sorghum flour. The reduction in fat and carbohydrate contents might be because of the way that biochemical and physiological changes happened during germination; such changes need the energy to continue, and therefore part of the seed fat was utilized for the production of this energy [22]. Adding spices to the germinated fermented batter of hulu-mur significantly $(P \leq 0.05)$ increase fiber, oil and carbohydrate contents, respectively. Baking (Aowasa) of hulu-mur batter significantly $(P \leq 0.05)$ increase the dry matter, ash, and fiber contents, and decreased protein and oil contents, respectively. In contrast Khalil, et al. [23] reported that baking had no impact on fatty and amino acid composition. However, it increased the $\mathrm{Na}$ and $\mathrm{Ca}$ levels, but decreased the $\mathrm{K}, \mathrm{P}$, and vitamin B5 amounts

\section{Carbohydrate content}

The amount of reducing sugars (\%) in Tabat and Feterita cultivars flour and theirbased foods was determined. As shown in Table 2 the fructose, glucose, sucrose, maltose, raffinose and total contents of Tabat flour was found to be $0.04 \%, 0.08 \%, 0.95 \%, 0.02 \%$, $0.08 \%$ and $1.24 \%$, respectively. Both glucose and raffinose contents of Tabat flour were lower than those of Feterita flour $(0.14 \%$ and $0.11 \%$, respectively), while no significant change observed in fructose, sucrose, maltose and total sugars between the two cultivars. As appeared in table (2) sucrose is the major soluble sugar in both cultivars followed by glucose and raffinose. Significant $(P \leq 0.05)$ reduction occurred in both sucrose and raffinose contents after processing of the two cultivars. There was a significant $(P \leq 0.05)$ increment observed in fructose, glucose and total sugars of baked hulu-mur in both cultivars, while maltose and total sugar fluctuated.

Table 2

Sugar content of Tabat, and Feterita sorghum cultivars flour and their-based foods on dry basis

\begin{tabular}{|l|l|l|l|l|l|c|}
\hline & & & & & \\
\hline
\end{tabular}

*For Abbreviations see Table 1. Values are means $( \pm \mathrm{SD})$. Values not sharing a common superscript in a column (for T, F and $\mathrm{S}$ separately) are significantly $(\mathrm{P} \leq 0.05)$ different. 


\section{Minerals content}

The mineral content $(\mathrm{mg} / 100 \mathrm{~g})$ of Tabat, and Feterita sorghum cultivars flour and their-based foods on a dry basis is shown in Table 3. From this table, it was clear that $\mathrm{K}$ and $\mathrm{P}$ contents were the most abundant minerals in both cultivars while $\mathrm{Pb}$ and $\mathrm{Cu}$ were the lowest ones. The potassium content of Tabat flour was $456.97 \mathrm{mg} / 100 \mathrm{~g}$ which was significantly $(P \leq 0.05)$ higher than that of Feterita flour $(427.64 \mathrm{mg} / 100 \mathrm{~g})$. The iron content of Tabat flour was found to be $11.26 \mathrm{mg} / 100 \mathrm{~g}$ which was significantly $(P \leq 0.05)$ lower than that of Feterita flour $(39.02 \mathrm{mg} / 100 \mathrm{~g})$. Fermentation of both flours during kisra preparation significantly $(P \leq 0.05)$ decreased $\mathrm{Ca}, \mathrm{K}, \mathrm{P}, \mathrm{Pb}$ and $\mathrm{Cu}$ contents, while there was a significant increase observed in $\mathrm{Fe}$ and $\mathrm{Mn}$ contents. A similar trend was observed by Oyewole \& Odunfa [24] during the fermentation of cassava. These researchers reported that the fermentation process caused reductions in the levels of potassium, copper, and phosphorus. In contrast, they showed that fermentation of cassava created an expansion in the concentration of calcium and a lessening in manganese, and iron. These results haven't agreed with results of Mahgoub, et al. [3] who found that fermentation during kisra processing has insignificant change on mineral contents. This may be because of the removal of antinutritional factors, by fermentation technology, which enhances the nutritional value of the food [24]. Baking of fermented kisra batter (Aowasa) of both cultivars significantly $(P \leq 0.05)$ increased all determined minerals $(\mathrm{Ca}, \mathrm{K}, \mathrm{P}, \mathrm{Fe}, \mathrm{Mn}, \mathrm{Pb}$ and $\mathrm{Cu}$ ) in both sorghum cultivars. Germination followed by fermentation plus the addition of spices of Tabat during processing of hulu-mur significantly $(P \leq 0.05)$ increased the content of all determined minerals.

Table 3

Minerals content (mg/100g) of Tabat, and Feterita sorghum cultivars flour and their-based foods on dry basis

\begin{tabular}{|l|l|l|l|l|l|l|c|}
\hline & & & & & & \\
\\
\hline
\end{tabular}

*For Abbreviations see Table 1. Values are means $( \pm \mathrm{SD})$. Values not sharing a common superscript in a column (for T, F and $\mathrm{S}$ separately) are significantly $(\mathrm{P} \leq 0.05)$ different. 


\section{— Food Technologies}

The mineral content of Abreh produced from Tabat cultivar is given in Table 3. This content was significantly different than that of Tabat flour. During Abreh processing the grains were decorticated and the bran was separated. This process decreased the content of minerals as shown in Table 3. The addition of spices followed by baking increased the mineral content of Abreh produced from Tabat flour. Akhtar, et al. [25] reported minor losses during baking of fortified whole wheat flour. Germination followed by fermentation plus the addition of spices of Feterita during processing of hulu-mur significantly $(P \leq 0.05)$ increased the contents of $\mathrm{Ca}, \mathrm{K}, \mathrm{Cu}$ and $\mathrm{Mn}$ minerals. While the contents of $\mathrm{P}, \mathrm{Fe}$ and $\mathrm{Pb}$ were decreased (Table 3).

\section{Amino acids}

Table 4 shows the amino acid content (g/100g protein) of Tabat, and Feterita sorghum cultivars flour and their-based foods (kisra, hulu-mur) on a dry basis. As shown in Table 4 glutamic, aspartic, leucine and proline represent the highest values among the whole amino acids of Tabat and Feterita and their-based foods (kisra, hulu-mur), whereas cyctine and methionine were the lowest ones. Youssef, [26] revealed that glutamic acid, leucine, alanine and proline were found in highest amounts among the amino acids of total protein of sorghum varieties. Osman, [15] reported a significant $(P \leq 0.05)$ decrease in glycine, lysine and arginine content of pearl millet during preparation of Lohoh when fermented for $24 \mathrm{~h}$.

The total amino acid in Tabat flour (92.63 g/100gm protein) was affected by fermentation and preparation as it was increased to 104.09 and $96.09 \mathrm{~g} / 100 \mathrm{gm}$ protein in TD and TK, respectively. Fermentation of Tabat flour resulted in a decrease in the level of nine amino acids (aspartic, serine, glutamic, valine, isoluecine, phenyle alanine, histidine, lysine and arginine) in TK. While Threonine, methionine, cysteine, proline, tyrosine, leucine, alanine and glycine were enriched during Kisra fermentation in Tabat sorghum studied (Table 4). El Tinay, et al. [27] found that fermentation of sorghum resulted in a decrease in the level of most of the essential amino acids. In a previous study El Tinay, et al. [19] investigated the nutritive value of sorghum Kisra and they showed no increase in lysine or threonine but tyrosine and methionine did increase.

The total amino acid in Tabat flour (92.63 g/100gm protein) decreased to 89.27, in MHBS as affected by germination and fermentation processes during Hulu-mur preparation, and it was increased to $91.63 \mathrm{~g} / 100 \mathrm{gm}$ in THAS as a result of spices addition. The previous amount was increased to $93.66 \mathrm{~g} / 100 \mathrm{gm}$ protein in $\mathrm{TH}$ as affected by the baking process. Mella, [21] reported an increase in free amino acids in the malted and fermented sorghum flour. Decortication of Tabat grains followed by a fermentation process for the batter decreased the total amino acid of Tabat flour from $92.63 \mathrm{~g} / 100 \mathrm{gm}$ protein to 92.96 in TABS and 88.36 in TAAS and 90.08 in TA. The content of eleven amino acids was decreased during Abreh processing and after addition of spices. While the content of glycine, alanine, leucine, tyrosine and proline was increased (Table 4). 
Table 4

Amino acids content (g/100g protein) of Tabat, and Feterita sorghum cultivars and their-based foods on dry basis*

*For Abbreviations see Table 1. Values are means ( $\pm S D)$.

\begin{tabular}{|l|l|l|l|l|l|l|l|l|}
\hline $\begin{array}{l}\text { Amino Acid } \\
\text { Sample }\end{array}$ & $\mathbf{T}$ & $\mathbf{T B}$ & $\mathbf{T K}$ & $\mathbf{T H B S}$ & $\mathbf{T H A S}$ & $\mathbf{T H}$ & $\mathbf{T A B S}$ & TAAS \\
\hline Aspartic & $8.20 \pm .04$ & $7.20 \pm .04$ & $7.32 \pm .05$ & $7.37 \pm .04$ & $7.09 \pm .04$ & $7.23 \pm .04$ & $6.73 \pm .04$ & $6.26 \pm .04$ \\
\hline Therionine & $3.38 \pm .02$ & $3.43 \pm .02$ & $3.41 \pm .03$ & $3.05 \pm .02$ & $2.86 \pm .01$ & $2.98 \pm .01$ & $3.07 \pm .02$ & $2.87 \pm .02$ \\
\hline Serine & $4.36 \pm .03$ & $4.46 \pm .03$ & $4.02 \pm .03$ & $3.68 \pm .02$ & $3.39 \pm .02$ & $3.62 \pm .04$ & $4.06 \pm .03$ & $3.74 \pm .02$ \\
\hline Glutamic & $18.72 \pm .07$ & $20.57 \pm .08$ & $17.93 \pm .08$ & $17.16 \pm .08$ & $17.78 \pm .09$ & $18.62 \pm .09$ & $18.71 \pm .09$ & $17.13 \pm .08$ \\
\hline Glysine & $2.86 \pm .01$ & $3.43 \pm .01$ & $3.66 \pm .02$ & $3.47 \pm .02$ & $3.49 \pm .02$ & $3.62 \pm .02$ & $3.17 \pm .02$ & $2.96 \pm .02$ \\
\hline Alanine & $7.59 \pm .04$ & $9.14 \pm .04$ & $8.90 \pm .06$ & $8.00 \pm .04$ & $8.57 \pm .06$ & $8.19 \pm .05$ & $8.71 \pm .06$ & $8.09 \pm .05$ \\
\hline Valine & $5.26 \pm .02$ & $5.37 \pm .04$ & $5.12 \pm .04$ & $4.53 \pm .02$ & $4.76 \pm .03$ & $5.00 \pm .04$ & $4.85 \pm .03$ & $4.52 \pm .03$ \\
\hline Isoleucine & $4.14 \pm .02$ & $4.80 \pm .03$ & $4.02 \pm .03$ & $3.68 \pm .04$ & $3.70 \pm .02$ & $3.94 \pm .03$ & $3.76 \pm .03$ & $3.48 \pm .02$ \\
\hline Leucine & $9.92 \pm .05$ & $12.57 \pm .06$ & $11.46 \pm .07$ & $10.74 \pm .06$ & $11.32 \pm .09$ & $11.38 \pm .08$ & $11.78 \pm .08$ & $10.70 \pm .07$ \\
\hline Tyrosine & $3.23 \pm .01$ & $6.17 \pm .02$ & $4.51 \pm .03$ & $4.32 \pm .03$ & $4.44 \pm .03$ & $4.79 \pm .03$ & $4.36 \pm .03$ & $4.17 \pm .03$ \\
\hline Ph. alanine & $5.64 \pm .03$ & $6.97 \pm .02$ & $5.37 \pm .04$ & $5.16 \pm .03$ & $5.50 \pm .04$ & $5.74 \pm .04$ & $5.64 \pm .03$ & $5.04 \pm .04$ \\
\hline Histidine & $2.71 \pm .01$ & $2.86 \pm .02$ & $2.56 \pm .02$ & $2.53 \pm .02$ & $2.54 \pm .02$ & $2.55 \pm .02$ & $2.28 \pm .02$ & $2.09 \pm .02$ \\
\hline Lysine & $2.93 \pm .02$ & $2.74 \pm .02$ & $2.68 \pm .01$ & $2.32 \pm .02$ & $2.22 \pm .02$ & $2.02 \pm .02$ & $2.18 \pm .02$ & $2.26 \pm .02$ \\
\hline Arginine & $4.44 \pm .03$ & $3.89 \pm .02$ & $4.15 \pm .02$ & $3.79 \pm .02$ & $3.70 \pm .03$ & $2.77 \pm .02$ & $3.37 \pm .02$ & $3.22 \pm .02$ \\
\hline Proline & $6.09 \pm .04$ & $8.00 \pm .04$ & $7.56 \pm .04$ & $6.84 \pm .05$ & $7.41 \pm .04$ & $7.45 \pm .04$ & $8.02 \pm .06$ & $7.57 \pm .05$ \\
\hline Cyctine & $1.58 \pm .01$ & $1.49 \pm .01$ & $1.71 \pm .01$ & $1.37 \pm .01$ & $1.38 \pm .01$ & $1.38 \pm .01$ & $1.29 \pm .01$ & $1.13 \pm .01$ \\
\hline Methionine & $1.58 \pm .01$ & $1.71 \pm .01$ & $1.71 \pm .01$ & $1.26 \pm .01$ & $1.48 \pm .01$ & $1.38 \pm .01$ & $1.29 \pm .01$ & $1.13 \pm .01$ \\
\hline Total & $\mathbf{9 2 . 6 3}$ & $\mathbf{1 0 4 . 8}$ & $\mathbf{9 6 . 0 9}$ & $\mathbf{8 9 . 2 7}$ & $\mathbf{9 1 . 6 3}$ & $\mathbf{9 3 . 6 6}$ & $\mathbf{9 2 . 9 6}$ & $\mathbf{8 8 . 3 6}$ \\
\hline
\end{tabular}

Continue of Table 4

\begin{tabular}{|l|l|l|l|l|l|l|l|}
\hline $\begin{array}{l}\text { Amino Acid } \\
\text { Sample }\end{array}$ & \multicolumn{1}{|c|}{ TA } & F & FB & FK & FHBS & FHAS & FH \\
\hline Aspartic & $6.33 \pm .05$ & $6.99 \pm .05$ & $6.77 \pm .04$ & $7.00 \pm .05$ & $6.91 \pm .05$ & $7.49 \pm .6$ & $7.52 \pm .04$ \\
\hline Therionine & $3.03 \pm .02$ & $2.68 \pm .02$ & $2.96 \pm .01$ & $3.17 \pm .02$ & $2.81 \pm .02$ & $3.05 \pm .03$ & $3.64 \pm .02$ \\
\hline Serine & $3.58 \pm .02$ & $3.58 \pm .02$ & $4.05 \pm .03$ & $3.92 \pm .02$ & $3.61 \pm .02$ & $3.95 \pm .03$ & $4.61 \pm .03$ \\
\hline Glutamic & $17.61 \pm .09$ & $19.35 \pm .09$ & $19.38 \pm .09$ & $18.58 \pm 0.2$ & $17.19 \pm 0.4$ & $17.04 \pm 0.6$ & $20.48 \pm 2.2$ \\
\hline Glysine & $3.21 \pm .02$ & $2.76 \pm .02$ & $2.80 \pm .02$ & $3.00 \pm .02$ & $2.89 \pm .02$ & $2.88 \pm .02$ & $3.76 \pm .02$ \\
\hline Alanine & $8.81 \pm .06$ & $8.37 \pm .05$ & $8.79 \pm .06$ & $9.25 \pm .08$ & $8.43 \pm .06$ & $7.90 \pm .05$ & $9.45 \pm .07$ \\
\hline Valine & $4.77 \pm .03$ & $4.63 \pm .03$ & $4.75 \pm .03$ & $5.08 \pm .03$ & $4.50 \pm .02$ & $4.44 \pm .03$ & $5.82 \pm .04$ \\
\hline Isoleucine & $3.67 \pm .03$ & $3.66 \pm .02$ & $3.66 \pm .02$ & $4.08 \pm .03$ & $3.61 \pm .02$ & $3.54 \pm .03$ & $4.12 \pm .03$ \\
\hline Leucine & $11.19 \pm .08$ & $12.11 \pm .08$ & $12.30 \pm 1.1$ & $12.50 \pm 0.1$ & $11.49 \pm 0.3$ & $11.03 \pm .09$ & $12.36 \pm .08$ \\
\hline Tyrosine & $4.40 \pm .03$ & $4.63 \pm .03$ & $4.59 \pm .03$ & $4.67 \pm .03$ & $4.26 \pm .03$ & $4.28 \pm .04$ & $5.45 \pm .04$ \\
\hline Ph. alanine & $5.50 \pm .04$ & $5.45 \pm .03$ & $5.45 \pm .04$ & $5.50 \pm .04$ & $5.30 \pm .04$ & $5.19 \pm .04$ & $6.30 \pm .05$ \\
\hline Histidine & $2.20 \pm .01$ & $2.44 \pm .02$ & $2.26 \pm .02$ & $2.42 \pm .02$ & $2.25 \pm .02$ & $2.14 \pm .02$ & $2.67 \pm .02$ \\
\hline Lysine & $2.57 \pm .02$ & $2.03 \pm .02$ & $2.02 \pm .02$ & $2.08 \pm .02$ & $1.77 \pm .02$ & $1.56 \pm .01$ & $2.91 \pm .02$ \\
\hline Arginine & $3.39 \pm .02$ & $3.74 \pm .02$ & $3.35 \pm .02$ & $3.67 \pm .03$ & $3.21 \pm .02$ & $3.37 \pm .02$ & $4.24 \pm .03$ \\
\hline Proline & $7.16 \pm .05$ & $7.89 \pm .05$ & $8.25 \pm .06$ & $8.08 \pm .06$ & $7.23 \pm .05$ & $7.00 \pm .05$ & $8.12 \pm .06$ \\
\hline Cyctine & $1.28 \pm .01$ & $1.30 \pm .02$ & $1.40 \pm .01$ & $1.50 \pm .01$ & $1.20 \pm .01$ & $1.07 \pm .01$ & $1.58 \pm .01$ \\
\hline Methionine & $1.38 \pm .01$ & $1.14 \pm .02$ & $1.25 \pm .01$ & $1.42 \pm .01$ & $1.20 \pm .01$ & $1.15 \pm .01$ & $1.70 \pm .02$ \\
\hline Total & $\mathbf{9 0 . 0 8}$ & $\mathbf{9 2 . 7 5}$ & $\mathbf{9 4 . 0 3}$ & $\mathbf{9 5 . 9 2}$ & $\mathbf{8 7 . 8 6}$ & $\mathbf{8 7 . 0 5}$ & $\mathbf{1 0 4 . 7 3}$ \\
\hline
\end{tabular}


The change in individual amino acids amount during the fermentation of Feterita and Feterita-based fermented foods is presented in Table 4. A significant $(P \leq 0.05)$ sharp increase in the total of amino acids was observed as the total amino acids of Feterita flour was 92.75 , this amount was increased to 94.03 as affected by batter fermentation, and it was increased to 95.92 after baking of the batter to produce kisra, and this amount reached 104.73 in Feterita hulu-mur. All the individual amino acids of Feterita flour were increased as a result of kisra batter fermentation, the amount of each individual amino acid in Feterita kisra was higher than that of Feterita flour. Popoola, [28] reported an increase in values for some of the amino acids in the fermented seeds of $C$. altissimum. Fermentation of grains has been accounted to expand free amino acids and their derivatives by proteolysis and/or by metabolic synthesis. Fermentation has been shown to increase the content of the essential amino acids lysine, methionine, and tryptophan [28]. Germination followed by cooking and fermentation during hulu-mur processing decreased the total amino acids of Feterita flour from 92.75 to 87.86 in Feterita hulu-mur batter before adding spices (FHBS) (Table 4) [29]. Fermentation did not realize any critical change in ash and oil contents, however, noteworthy diminishing was seen in crude protein, crude fiber, starch, total and insoluble dietary fiber contents. Another increment in the amount of each individual amino acid was observed in the final Feterita hulu-mur $(\mathrm{FH})$ as a result of spices addition and baking of hulu-mur batter.

\section{Amino acids score}

Table 5 shows the amino acid score of Rabat, and Feterita sorghum cultivars flour and their-based products on a dry basis.

Table 5

Amino acids score of Tabat, and Feterita sorghum cultivars flour and their-based products on dry basis*

\begin{tabular}{|c|c|c|c|c|c|c|c|c|c|c|c|c|c|c|c|}
\hline 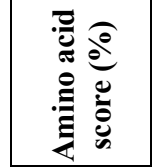 & $r$ & $\stackrel{\oplus}{\vec{P}}$ & $\mathscr{F}$ & 苗 & 胥 & $\mathbb{E}$ & 象 & $\sum_{1}^{\infty}$ & 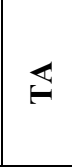 & L & $\frac{m}{I}$ & $\frac{V}{I}$ & 苗 & $\sum_{x}^{\infty}$ & $\vec{T}$ \\
\hline Therionine & 84.60 & 85.71 & 85.37 & 76.3 & 71.4 & 74.47 & 76.7 & 71.7 & 75.7 & 67.1 & 73.9 & 79.2 & 70.3 & 76.1 & 90.9 \\
\hline Valine & 105.3 & 107.4 & 102.4 & 90.5 & 95.4 & 100.0 & 97.0 & 90.4 & 95.4 & 92.7 & 94.9 & 101.7 & 89.9 & 88.9 & 116.4 \\
\hline Isoleucine & 103.4 & 120.0 & 100.6 & 92.1 & 92.6 & 98.4 & 94.1 & 86.9 & 91.7 & 91.5 & 91.4 & $\mid 102.1$ & 90.4 & 88.5 & 103.0 \\
\hline Leucine & 141.8 & 179.6 & 163.8 & 153.4 & 161.8 & 162.6 & 168.3 & 152.8 & 159.9 & 173.1 & 175.7 & 178.6 & 164.1 & 157.6 & 176.6 \\
\hline Tyr + PA & 147.9 & 219.1 & 164.6 & 157.9 & 165.8 & 175.5 & 166.8 & 153.6 & 165.1 & 168.0 & 167.3 & 169.4 & 159.3 & 157.8 & 195.9 \\
\hline Lysine & $53 . .32$ & 49.9 & 48.8 & 42.1 & 40.4 & 36.8 & 39.6 & 41.1 & 46.7 & 36.95 & 36.8 & 37.9 & 32.1 & 28.4 & 52.9 \\
\hline $\mathrm{Cy}+\mathrm{Met}$ & 89.71 & 90.91 & 97.01 & 74.76 & 81.2 & 78.6 & 73.1 & 64.2 & 75.6 & 69.3 & 75.2 & 82.9 & 68.5 & 63.1 & 92.9 \\
\hline
\end{tabular}

*For Abbreviations see Table 1. $\mathbf{T y r}+\mathbf{P A}=$ Tyrosine + P. alanine, $\mathbf{C y}+$ Met $=$ Cyctine + methionine. Values are means of duplicate determinations.

For both Tabat and Feterita flour, lysine was found the first limiting amino acids with values of $53.32 \%$ and $36.95 \%$, respectively. The second limiting amino acid was threonine followed by cystine + methionine for both cultivars. Fermentation of both cultivars during kisra processing, increased threonine, cystine + methionine scores, while lysine score was decreased. Baking of kisra increased Cy + Met score from 89.71 to 97.0 and it decreased lysine score from 53.32 to 48.8 in Tabat and Ferterita respectively. Germination followed by cooking and then fermentation in hulu-mur processing decreased all the amino acids 
except leucine and Tyr + PA which was increased sharply. Baking of Tabat hulu-mur decreased all amino acid scores except leucine and Tyr + PA which were increased when compared to Tabat flour (Table 5). In abreh processing seeds were fermented, decorticated, fermented and cooked, then baked these processes decreased the amino acid scores of valine, isoleucine, threonine, lysine, and Cy + Met from 105.3, 103.4, 84.60, 53.32, and 89.71, in Tabat flour to 95.4, 91.7, 75.7, 46.7, and 75.6 in TA, respectively. While the scores of leucine and Tyr + PA were increased from 141.8 and 147.9 in Tabat flour to 159.9 and 165.1 in TA respectively (Table 5).

Microbial analysis and total viable count of bacteria: Table (6) shows the microbiological load (cfu/g) of kisra, Abreh and hulu-mur batters of Tabat, and Feterita sorghum cultivars. From this table, it was clear that there was a significant difference $(\mathrm{P}<0.05)$ in total lactic acid bacteria count of TKD $\left(7.25 \times 10^{5}\right)$, THAS $\left(5.15 \times 10^{5}\right)$, THBS $\left(5.65 \times 10^{6} \mathrm{CFU} / \mathrm{g}\right)$, TABS $\left(4.15 \times 10^{5}\right)$, and TAAS $\left(5.05 \times 10^{4}\right)$. As shown the differences might be related to each batter fermentation time and different process steps, as in TKD only fermentation while in hulu-mur batter there besides fermentation there were germination and cooking processes. From table 6 , there were significant differences $(P<0.05)$ in yeast and mold count of Feterita batter, as in FKD this account was $3.20 * 10^{3}$, and it was significantly $(P<0.05)$ increased to $4.75^{*} 10^{3}$ in FHBS and to $6.50^{*} 10^{2}$ in FHAS. These outcomes are in agreement with Sulieman et al. [30] who reported high yeast counts in Hulu-mur batter samples. The increase in lactic acid bacteria and yeast counts in these batters could be due to the long fermentation time and the availability of essential nutrients in Tabat and Feterita. Probably added spices has provided more nutrients, particularly minerals, and consequently resulted in more favorable conditions for growth of yeast, hence more yeast count in TAAS compared to TABS and the same trend in FHAS compared to FHBS. Sulieman et al. [30], found that addition of spices to Hulu-mur batter stimulated yeast growth during fermentation. The increase in microbial counts of kisra batter is in agreement with Mohammed, et al. [31] who reported an increase in both bacterial and yeast counts of Kisra batter as a result of fermentation.

\section{Acrylamide content}

In this study 20 kisra samples made from Tabat and Feterita cultivars were collected from Khartoum, Omdurman and Bahri states. No acrylamide content was found in all samples except one sample of the Tabat kisra obtained from Omdurman State contained (22 $\mu \mathrm{g} / \mathrm{kg}) .15$ hulu-mur samples made from Feterita cultivar were collected from different states. From those entire 15 samples just one obtained from Shendi state contained acrylamide with a value of $(84 \mu \mathrm{g} / \mathrm{kg}$ ) (data not shown). The occurrence of acrylamide in those two samples might be due to differences in the preparation of hulu-mur and kisra in each state. Omer, [32] measured acrylamide in hulu-mur using 3 different methods for determination and found that the values of acylamide are $51.50 \mathrm{ug} / \mathrm{kg}, 59.43 \mathrm{ug} / \mathrm{kg}$ and not detected according to the method used.

\section{Conclusions}

In conclusion sorghum cultivars (Tabat and Feterita) and their final products (Kisra and hulu-mur) contain great levels of carbohydrate, protein, K, P, Fe, Mn and essential amino acids (Valine, isoleucine, leucine, tyrosine, and phenylalanine, while lysine, threonine and sulfur amino acids were insufficient. Acrylamide was found in two samples 


\section{— Food Technologies}

(Tabat kisra and Ferterita hulu-mur) of 35 samples analyzed in amounts less than 0.2 $\mathrm{mg} / \mathrm{kg}$ which confirm that traditional Sudanese food at this study (hulu-mur and kisra) are safe for human consumption. Further research must be done to detect the level of acrylamide in coffee, cookies like biscuits, and other traditional Sudanese homemade cookies, which ammonium bicarbonate is utilized as additives because it is one of the primary materials induce the formation of acrylamide. Acrylamide was detected in two samples Tabat kisra $(22 \mu \mathrm{g} / \mathrm{kg})$, and Ferterita hulu-mur $(84 \mu \mathrm{g} / \mathrm{kg})$ only.

Acknowledgement: The authors are grateful to the Sudanese Standards and Metrology Organization for financing this research.

\section{References}

1. Mohamed O. E. F. (2002), Supplementation of sorghum with chickpea and nutritional evaluation, M.Sc. Thesis, Faculty of Agriculture, University of Khartoum, Khartoum.

2. Llopart E.E., Drago S.R. (2016), Physicochemical properties of sorghum and technological aptitude for popping, Nutritional changes after popping, LWT-Food Sci. Tech., 71, pp. 316-322.

3. Mahgoub S.E.O., Ahmed B.M., Ahmed M.M.O. \& El Agib E.N.A.A. (1999), Effect of traditional Sudanese processing of kisra bread and hulu-mur drink on their thiamine, riboflavin and mineral contents. Food Chem., 67, pp. 129-133.

4. Keramat J., LeBail A., Prost C., \& Jafari M. (2011), Acrylamide in Baking Products: A Review, Food Bioprocess Technol., 4, pp. 530-543.

5. Dirar H.A. (1993), Indigenous fermented foods of the Sudan. CTA., Technical Center for Agriculture and Rural Cooperation, Wageningen.

6. AOAC (2012), Official Methods of Analysis of the Association of Official Analytical Chemist. No.994.12, chapter 4. pp. 9-13. $19^{\text {th }}$ Edition, Revision.

7. Stipanuk M. H., \& Caudill M. A. (2013), Biochemical, physiological, and molecular aspects of human nutrition, 3rd edn. St. Louis, Mo: Elsevier/Saunders.

8. Aladedunye F. A., Matthäus B. \& Przybylski R. (2011), Carbon dioxide blanketing impedes the formation of 4-hydroxynonenal and acrylamide during frying. A novel procedure for HNE quantification, Eur. J. Lipid Sci Tech., 113(7), pp. 916-923.

9. Matthäus B., Haase N.U., \& Vosmann K. (2004),Factors affecting the concentration of acrylamide during deep-fat frying of potatoes, Eur. J. Lipid Sci. Tech., 106(11), pp. 793801.

10. Harrigan W.F. (1998), Laboratory Methods in Food Microbiology, Academic Press, San Diego, USA.

11. Bewick V. Cheek L. \& Ball J. (2004), Review Statistics review 9: One-way analysis of variance, Critical Care, 8 (2), pp. 130-136.

12. Toum S.A.E.M. (2009), Nutritional evaluation of Sorghum (Sorghum bicolor L. Monech) flour supplemented with white bean (Phaseolus vulgaris) M. Sc. Thesis, University of Khartoum, Sudan.

13. Awadelkareem A. M., Hassan E. G., Fageer A. h.M., Sulieman A.M.E. \& Mustafa A. M. I. (2015), The nutritive value of two sorghum cultivar, Int. J. Food Nut. Sci., 4(1), pp. 1-7.

14. Adams M. R. (1990), Topical aspects of fermented foods, Trend Food Sci. Tech., pp. 141144.

15. Osman M. A. (2011), Effect of traditional fermentation process on the nutrient and antinutrient contents of pearl millet during preparation of Lohoh, J. Saudi Soc. Agric. Sci., 10 , pp. $1-6$. 


\section{— Food Technologies}

16. Ogbonna A. C., Abuajah C. I., Ide E.O., \& Udofia U.S. (2012), Effect of malting conditions on the nutritional and anti-nutritional factors of sorghum grist, The Annals of the University Dunarea de Jos of Galati Fascicle VI AUDJG - Food Tech., 36(2), pp. 64-72.

17. Kim S.T., Wang Y., Kang S.Y., Kim S.G., Rakwal R., Kim Y.C. \& Kang K.Y. (2009), Developing rice embryo proteomics reveal an essential role for embryonic proteins in regulation of seed germination, J. Proteome Res., 8(7), pp. 3598-3605.

18. Suganya P., \& Kailappan R. (2013), Changes in Nutritional Quality of Traditional Fermented Food Made from Pearl Millet, Inter. J. Sci Res., 2(12), pp. 4-6.

19. El Tinay A. H., Abd-el Gadir A. M. \& Elhidia M. (1979), Sorghum fermented kisra bread. 1. Nutritive value of kisra, J. Sci. Food Agric., 30, pp. 859-863.

20. Elkhalifa A. O., Ali A.M., El Tinay, A. H. (2007), Fermented sorghum foods of Sudan - a review, J. Food Sci. Technol., 44(4), pp. 343-349.

21. Mella, Onesmo N.O. (2011), Effects of Malting and Fermentation on the Composition and Functionality of Sorghum Flour. M.Sc. Thesis in Food Science and Technology, The Graduate College at the University of Nebraska, USA.

22. Elmaki H. B., Babiker E.E., \& El Tinay A. H. (1999), Changes in chemical composition, grain malting, starch and tannin contents and protein digestibility during germination of sorghum cultivars, Food Chem., 64, pp. 331-336.

23. Khalil J. K., Sawaya W. N., Safi W. J., \& Al-Mohammad H. M. (1984), Chemical composition and nutritional quality of sorghum flour and bread, Plant Foods Hum. Nutr., 34(2), pp. 141-150.

24. Oyewole O. B., \& Odunfa S. A. (1989), Effects of Fermentation on the Carbohydrate, Mineral, and Protein Contents of Cassava during 'Fufu' Production, J. Food Comp. Anal., 2(2), pp. 170-176.

25. Akhtar S., Anjum F.M. Ur-Rehman S. \& Sheikh M.A. (2010), Effect of storage and baking on mineral contents of fortified whole wheat flour, J. Food Proc. Pres., 34(2), pp. 335-349.

26. Youssef A. M. (1998), Extractability, fractionation and nutritional value of low and high tannin sorghum proteins, Food Chem., 63, pp. 325-329.

27. El Tinay A. H., El Mahdi Z. M. \& El Soubki A. (1985), Supplementation of fermented sorghum Kisra bread with legume protein isolates, J. Food Tech., 20, pp. 679-687.

28. Popoola T.O.S., Jolaoso A.A. \& Akintokun A.A. (2005), An assessment of the nutritional value of oso- a condiment made by fermenting seeds of Cathormion altissimum, J. Food Tech., 3 (2), pp. 149-151.

29. Arora S., Jood S. \& Khetarpaul N. (2010), Effect of germination and probiotic fermentation on nutrient composition of barley based food mixtures, Food Chem., 119, pp. 779-784.

30. Abdel Moneim E. Sulieman1, Esra A.M , Warda S. (2015), Abdelgadir Isolation and Identification of Yeasts from the Different Stages of Hulu-mur Fermentation, J. Microb. Res., 5(2), pp. 71-76.

31. Mohammed S.I., Steenson L.R., \& Kirleis L.W. (1991), Isolation and Characterization of Microorganisms Associated with the Traditional Sorghum Fermentation for Production of Sudanese Kisra, Appl. Enviro. Microb., 57(9), pp. 2529-2533.

32. Omar M. M. A., Elbashir A. A., Schmitz O. J. (2015), Determination of acrylamide in Sudanese food by high performance liquid chromatography coupled with LTQ Orbitrap mass spectrometry, Food Chem., 176, pp. 342-349. 